\title{
$\mathrm{Al}$ 薄膜形成，加熱，焼入れおよび窒化による SKD61 ダイス鋼の表面改質
}

\author{
过 新 次* 古澤利 明* \\ 斎藤哲男** 鎌田正彦*** \\ *帝京大学理工学部機械・精密システム工学科 \\ **栃木県工業技術センター機械金属部 \\ ***日本電子工業株式会社技術部
}

J. Japan Inst. Metals, Vol. 63, No. 2 (1999), pp. 145-151

\section{Surface Modification of SKD61 Die Steel by Forming of an Al Thin Film, Heating, Quenching and Nitriding}

Shinji Tsuji*, Toshiaki Furusawa*, Tetsuo Saito** and Masahiko Kamada***

\author{
*Department of Mechanical and Precision System, School of Science and Engineering, Teikyo University, \\ Utsunomiya 320-8551 \\ ** Mechanical Engineerings and Metals Division, Industrial Research Institute of Tochigi Prefecture, \\ Kanuma 322-0011 \\ ***Department of Engineering, Nihon Denki Kogyo Co. Ltd., Sagamihara 229-1112
}

The surface modification of SKD61 die steel has been studied by a complex process consisting of, at first, physical vapor deposition of an $\mathrm{Al}$ thin film from 0.6 to $4.4 \mu \mathrm{m}$ (step 1), diffusional dilution of the film into the matrix under vacuum heating at $1298 \mathrm{~K}$ for $1.8 \mathrm{ks}$ (step 2), gas quenching (step 3), and plasma-nitriding at 813 $\mathrm{K}$ or $853 \mathrm{~K}$ for $14.4 \mathrm{ks}$ ( $\mathrm{step} 4$ ) at last.

The results for the steps from 1 to 3 are as follows. (1) The thickness of the Al-diffused layer increases with the thickness of the $\mathrm{Al}$ thin film. The $\mathrm{Al}$ content at the most outer surface also increases with the thickness of the Al thin film. (2) The Al-diffused layer shows the hardness of about HV270, and the matrix shows the hardness of about HV610 corresponding to the die steel quenched. (3) The previously reported model for treating multiphase diffusion during the process of homogenization for diffusion couples has been applied to this $\mathrm{Al}$ thin film/die steel couple. The numerically calculated profiles of $\mathrm{Al}$ content agree well with the experimentally obtained ones.

The results for the steps from 1 to 4 are as follows. (4) The nitriding zone obtained consists of the Al-diffused nitriding layer, and the nitriding layer of the matrix. The total thickness of both the nitriding layers almost remains constant regardless of the thickness of the $\mathrm{Al}$ thin film. (5) The surface hardness of the Al-diffused nitriding steel slightly increases with the thickness of the Al thin film.

(Received July 29, 1998; In Final Form October 8, 1998)

Keywords: surface modification, die steel, aluminum thin film, diffusional dilution, aluminum-
diffused layer, quenching, plasma-nitriding, nitriding layer, layer thickness, surface hardness

\section{I. 緒言}

著者の一人は，スパッタリングによる鋼表面への $\mathrm{Al}$ 薄膜 形成，真空中加熱による挔散希䣋，その後のプラズマ窒化よ り成る複合化処理により，5Cr-1 1/4 Mo-1V ダイス鋼の表面 硬化を試み，午の結果，窒化さ祅た $\mathrm{Al}$ 搪散層の断面は HV1400にも達する高い硬さ值を示すことを報告した(1).

$\mathrm{Al}$ 薄膜形成・拡散・窒化処理を例えば工具鋼部品などに
適用する場合を考夏てみると，高い拡散処理温度を必要とす るため，拡散処理後に焼入れを行う必要がある。しかし，焼 入れのための加熱を搪散処理後に別に行らことは，エネルギ 一消費, 経済性扰よび $\mathrm{A} 1$ 拡散層厚さの制御などからみて問 題があり，これらの処理は同一工程で行うことが望ましい. このよらな観点から，まず，本研究においては焼入れ操作を 拡散温度での加熱保持終了直後に取り入れることを検討した。

本研究に物いては，供試材として前報 (1) と同じ5Cr$11 / 4 \mathrm{Mo}-1 \mathrm{~V}$ ダイス鋼，すなわちSKD61を用いることにし 
た. なた，相互拡散のための加熱とオーステナイト化のため の加熱とを同一工程で行うことにし，その基準加熱条件とし て $1298 \mathrm{~K}-1.8 \mathrm{ks}$ を選んだ.この条件での加熱および加熱後 焼入れ硬化した供試片に関して， $\mathrm{Al}$ 拡散層厚さの $\mathrm{Al}$ 薄膜厚 さへの依存性, ならびにその後のプラズマ窒化によって形成 された窒化層の厚さ拉よび硬さの $\mathrm{Al}$ 薄膜厚さへの依存性を 調べた.さらに窒化過程に执いて, 窒素の鋼材内部への拡散 浸透による炭素濃度分布への影響を究明した。

\section{II. 実 験 方 法}

本研究では，表面改質を Fig. 1 に示す順序で行った。す なわち，スパッタリングによる鋼表面上での $\mathrm{Al}$ 薄膜形成, 真空中加熱による $\mathrm{Al}$ の鋼中への拡散，ガス焼入れによる下 地母材の焼入れ硬化, ならびにプラズマ窒化による $\mathrm{Al}$ 拡散 層扣よび下地母材の硬化よりなる複合化処理により, 全体と して傾斜硬さを有する表面硬化を行った．各処理などの詳細 は以下の通りである。

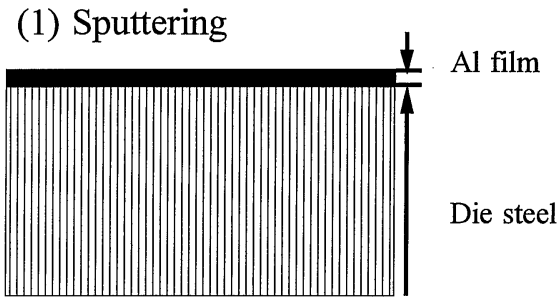

(2) Heating in vacuum

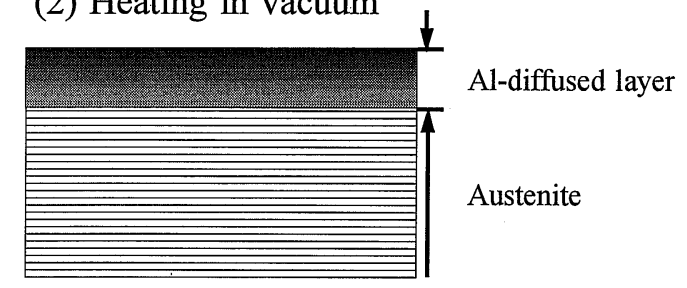

(3) Quenching

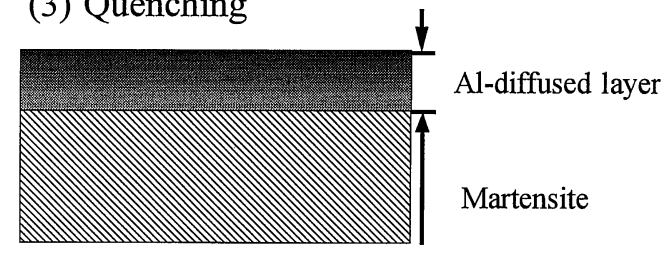

(4) Plasma nitriding

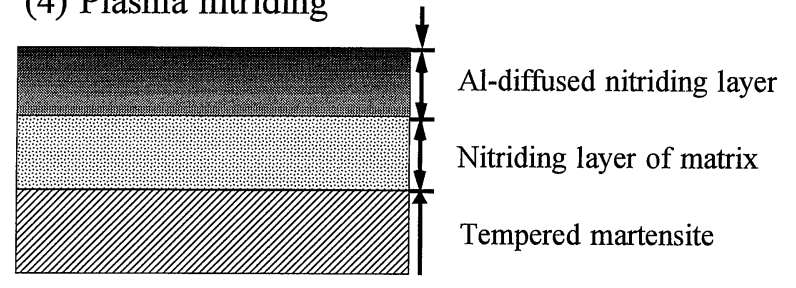

Fig. 1 Schematic presentation of the surface hardening of SKD61 by the complex process consisting of vapor deposition of $\mathrm{Al}$, heating, quenching, and nitriding.

\section{1. 供試材}

前報(1) と同じ市販の合金工具鋼 SKD61 を供試材として用 いた。試料はフライス盤を用いて $32 \mathrm{~mm} \times 20 \mathrm{~mm} \times 6 \mathrm{~mm}$ の長方形に加工し，Al 薄膜を形成する面に関しては研削仕 上げを行った。 また試料の厚さ方向には $\phi 2.5$ の孔, 試料 の長手方向には一端から他端表面にできるだけ近接するよう に $\phi 3.2 \mathrm{~mm}$ の孔を開け, 前者は真空加熱時に扣いて試料を 懸垂するためのワイヤー用孔として, 後者はプラズマ窒化時 に执いて熱電対を挿入するための孔として用いた．研削仕上 げした試料表面を研磨拈よび挀磨によって鏡面状に仕上げ， メタノール拉よびアセトン中にて超音波洗浄したものをスパ ッタリングに供した.

\section{2. スパッタリング}

前報(1) と同じスパッタリング装置, ターゲットおよび $\mathrm{Ar}$ ガスを用い，また同様の蒸着条件で試料上に約 $0.6 \sim 4.4 \mu \mathrm{m}$ 厚さの $\mathrm{Al}$ 薄膜を形成した. スパッタリングによって得られ た $\mathrm{Al}$ 薄膜の厚さは次に述べる膜放射蛍光 $\mathrm{X}$ 線法 ${ }^{(2)}$ に基づい て決定した。 い亦, 試料に入射する一次 X 線の強さが一定 であると考光, 厚さ $t$ の $\mathrm{Al}$ 膜が放射する蛍光 $\mathrm{X}$ 線, すなわ ち $\mathrm{AlK} \alpha$ 線, の強さを $I_{\mathrm{t}}$ とする.一方, バルクの $\mathrm{Al}$ から放 射する $\mathrm{AlK} \alpha$ 線の強さを $I_{\infty}$ とすると, 両者の間には次の関 係が成り立つ.すなわち

$$
\ln \left[1 /\left(1-I_{\mathrm{t}} / I_{\infty}\right)\right]=k t
$$

ここに $k$ は定数である．まず，幾つかの異なった厚さの $\mathrm{Al}$ 薄膜を冷間鋼板 SPCE 基板上に形成して, スパッタリング 前後の質量差から $\mathrm{Al}$ 薄膜の厚さを求め, この厚さ測定と蛍 光 $\mathrm{X}$ 線分析との結果から式 (1)に基づく検量線を作成した. この際, 質量差を大きくとるために鋼板基板としては試料容 器に装入できる最大寸法のものを用いた. 試料の $\mathrm{Al}$ 薄膜の 厚さは蛍光分析結果から上記の検量線を用いて決定した。な 扣予備調査として，ガラス基板上の $\mathrm{Al}$ 薄膜の酸溶解による 質量減少の測定和よび表面粗さ測定に基づく $\mathrm{Al}$ 薄膜の厚さ 決定法を検討したが，上記のスパッタリング前後に拈いて質 量を測定する方法が最も信頼できることがわかった.

\section{3. 拡散加熱および焼入れ}

スパッタリングによって各種厚さの $\mathrm{A} 1$ 膜を形成した試料

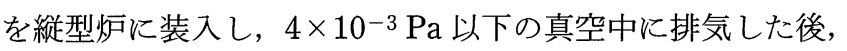
$12.5 \mathrm{~K} / \mathrm{min}$ の速度で加熱し, $1298 \mathrm{~K}$ で $1.8 \mathrm{ks}$ 間加熱した. 続いて，炉内を下方から上方へと流れる $5 \% \mathrm{H}_{2}-95 \% \mathrm{~N}_{2}$ ガス に切り換え, 試料を加熱帯下部に移動することによって急 冷, 焼入れを行った。 な㧊, 加熱温度の $1298 \mathrm{~K}$ は JIS ${ }^{(3)}$ に 規定された焼入れ温度領域の中央值を採用し, 加熱時間の $1.8 \mathrm{ks}$ は焼入れ加熱に和ける一般的な保持時間(4)を採用し た. ここで, 試料は炉容積に比較して小さく, 昇温速度も緩 やかであるので, 試料温度は, 大きな温度差を伴らことな く, 炉温度に追随していくと考えられる. したがって, 設定 
温度での保持時間は実際に試料温度がその設定温度に保持し た時間に等しいと考兑た。

\section{4. プラズマ達化}

暁入れ後の試料は僅かに酸化されているため，1000番の 研磨紙を用いて研磨後, 前報(1) と同じプラズマ窒化装置, 各 種ガスを用い，また同様の条件和よび方法で窒化を行った。 な拉，上記酸化膜は窒化に先立つアルゴン・水素混合がスで のクリーニング(1)で，異常放電を生じることなく，除去さ れ，その表面状況叔よび窒化層硬さ・憬さに関しても研磨試 料のそられとの違いが認められなかった。窒化は813または $853 \mathrm{~K}$ で $14.4 \mathrm{ks}$ 間行った。 JIS ${ }^{(3)}$ に基づくと本鋼種の焼戻 乙温度は 773〜803 K である.プラズマ嗐化温度はそれより やや高い温度ではあるが，本プラズマ窒化処理は暁き戻し処 理も兼悋ることになる。

\section{5. 光学顕微鏡観察}

試料の埋め込み抏よび研磨方法は前報(1)と同じでする。拡 散加熱・焼入れ後の試料执よびプラズマ窒化後の試料に関し て，光学顕貒鏡観察を行った。なお，焼入れ試料扣よび窒化 試料の腐食剤としては,それぞれ, Vilella 液 $(5 \mathrm{ml}$ 塩酸, 1 $\mathrm{g}$ ピクリン酸, $100 \mathrm{ml}$ エチールアルコール) 和よび $5 \%$ ナイ タール液を用いた。

\section{6. 分析および硬さ測定}

EPMA 分析装置(島津製作所製，EPMA-8705）を用いて， $\mathrm{A} 1$ 拡散層に関する点分析を行った．測定条件は加速電圧 25 $\mathrm{kV}$, 試料電流 $0.36 \mathrm{nA}$ であり, 電子線のコンタミネーショ ンょり，分析点の位置を求めた。な抏，補正法としては ZAF 法を用い，分光結晶としてはRAPを用いた。プラズ マ窒化後の試料以関してはEPMA-1600を用いて線分析を 行った。測定条件は加速電圧 $10 \mathrm{kV}, \mathrm{NK} \alpha$ の分光結晶として はLSA55を，CK $\alpha$ にはPbSTを用いた。窒化試料表面の 同定にはX線回折装置(理学電気, RINT 2000)を用いた. 測定条件は加速電圧 $40 \mathrm{kV}$ であり，X線源にはCuK $\alpha$ 線を
用いた。

超微小硬度計 (明石製作所製，MVK-G3) 学用いて，断面 および表面の硬さ測定を行った。断面硬さ測定执よび表面硬

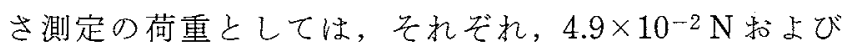
$9.8 \times 10^{-1} \mathrm{~N}$ 用いた。

\section{III. 実験結果および考察}

本研究のように, 拡散温度が高温で, しかもA $\mathrm{A}$ 薄膜の厚 さが薄い場合には，Al 薄膜と鋼との間で新相の出現および 成長, 既存相の消失といった複雑な拡散過程を経た後, 拡散 加熱後の鋼表面には $\mathrm{Al}$ を含むつェライトのみが新相として 形成される(5)。したがって，ある一定時間を過ざた拡散過程 では，Al 应散層であるフェライトと母材オーステナイトと の間には，Fig. 2 に示すよらに，ほぼ直線上の異相界面が 形成される。また，図に乱いては，Al 払散層には表面に対 してほぼ垂直方向に粒界を持つ柱状晶が，母材内部では焼入 れによるマルテンサイト組織が観察される。焼入れ後の試料 を表面観察や断面顕微鏡観察した結果, 焼入れに伴って, $\mathrm{Al}$ 拡散層に亀裂を生じることや， $\mathrm{Al}$ 拡散層が母材から剥離 するような現象は認められなかった。

本研究のような一定加熱条件では，Fig. 3 に示すように， 拡散層の厭さは $\mathrm{Al}$ 薄膜厚さとともに増加するが, 増加の割 合は $\mathrm{Al}$ 薄膜厚さとともに減少していく㑯向を示す。的， 本研究のような $1298 \mathrm{~K} て ゙ 1.8 \mathrm{ks}$ 加熱ならびに $4.4 \mu \mathrm{m}$ 以下 の Al 薄膜厚さといら条件下に执いては, $\mathrm{Al}$ 薄膜厚さの約 11 倍以上の厚さの拡散層が形成されることが図から明らかであ る、既に著者の一人らは新相の出現および既存相の消失を伴 い，濃度の均一化に向かって進行する2元系多相拡散をシ ミニレートする数值計算法を明らかにし，年の適用例の一つ として，1273 $\mathrm{K}$ で加熱した $3.0 \mu \mathrm{m}$ 厚さの $\mathrm{Al}$ 薄膜 $/ \mathrm{Fe}$ バル ク刘に生じる反応拉散の時間的変化をシミュレートした(5). その結果, 早くも加熱 $26.4 \mathrm{~s}$ 後に和いて液体 $\mathrm{Al}$ 相, 拉よび いったん拡散效に生成した $\mathrm{Fe}_{2} \mathrm{Al}_{5}, \mathrm{FeAl}_{2}$ 相がすべて消失 し，拡散対には $\alpha$ 相と $\gamma$ 相のみが存在することを明らかに

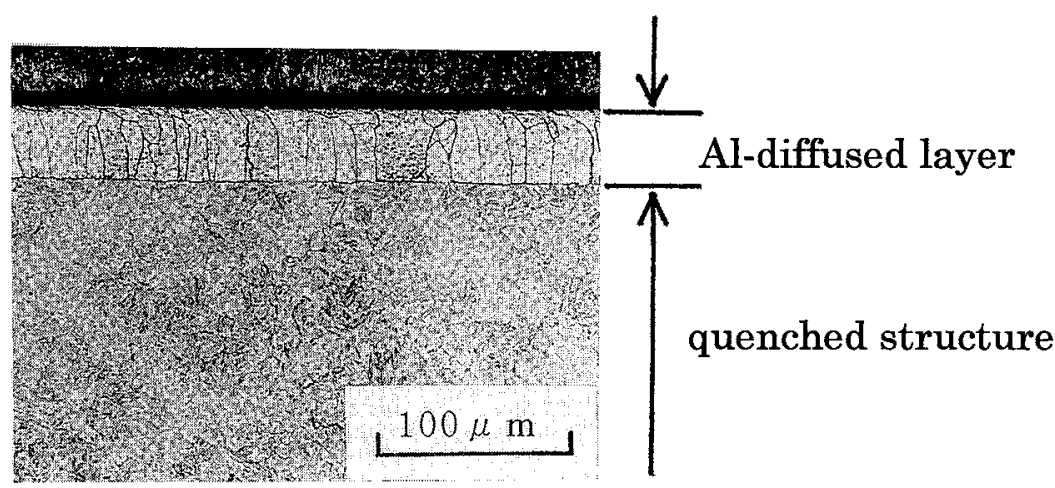

Fig. 2 Optical micrograph showing the cross section of the specimen which was Al-diffused and quenched. Thickness of the Al thin film: $2.5 \mu \mathrm{m}$. 


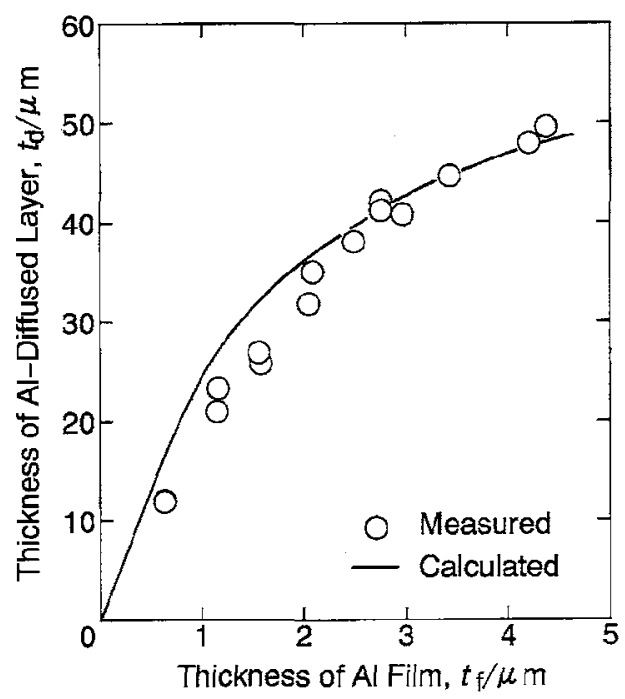

Fig. 3 Experimentally measured and numerically calculated dependences of the thickness of the Al-diffused layer upon that of the Al thin film.

した。

上記ならびに $\gamma$ 相の相互拡散係数が非常に小さな值である ことから， $\alpha$ 相の層幅は $\alpha$ 相の相互拡散係数の值に強く依存 することが明らかである。そこで， $\mathrm{Al}$ 拡散層の厚さが数值 計算値と実験値とで一致するように， $\alpha$ 相の相互执散係数の 値を文献(5)の $2.59 \times 10^{-13} \mathrm{~m}^{2} / \mathrm{s}$ から $2.2 \times 10^{-13} \mathrm{~m}^{2} / \mathrm{s}$ へ之変 克，拡散層厚さの $\mathrm{A} 1$ 薄膜厚さへの依存性を計算してみた。 その結果を Fig. 3 K実線で示す。な拉， $\alpha$ 相以外の他の相に 関する相境界組成扣よび相互拡散係数などの值は文献 (5) と同 一の值を用い，相境界組成 $\alpha /(\alpha+\gamma)$ の

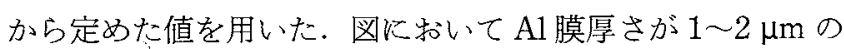
範用では計算值はやや大さい值を示するのの，計算結果は全 体として拉散層厚さの $\mathrm{Al}$ 膜厚さへの依存性をよく説明して いる。

Fig. 3の試料の中から選び出した 3 個の試料に関して， EPMA 測定和よび ZAF 補正によって得た $\mathrm{Al}$ 濃度分布曲線 とシミニレーションから得たそれらとをFig. 4 に示す。図 から，Al 膜厚さとともに拡散層厚さ掞よび表面 $\mathrm{Al}$ 濃度が増 加することが認められる。一方， $\mathrm{Al}$ 濃度分布曲線を表面か らの距離に関して数值積分すると，単位表面積あたりのAl モル数が得られる。シミュレーションによる $\mathrm{Al}$ 濃度分布曲 線から得た $\mathrm{Al}$ モル数と膜厚さに対応する $\mathrm{Al}$ モル数との一 致性がよいことは既に述べた(5)。したがって，図に拈いて認 められる，実験的に定めた $\mathrm{Al}$ 濃度推移曲線に対応する $\mathrm{Al}$ モル数がシミュレーションによるそれらに比較して小さいこ とは，明らかに，実験的に $\mathrm{Al}$ 濃度推移曲線を定める過程に 関して何らかの問題点があるよらに考兄られる。これについ ては，Al拡散層厚さの均一性， EPMA 測定执よび補正計算 による $\mathrm{Al}$ 濃度の決定, 常光 $\mathrm{X}$ 線分析による $\mathrm{Al}$ 膜厚さの決 定などに関して詳細な検討を行ったが，その原因に関しては

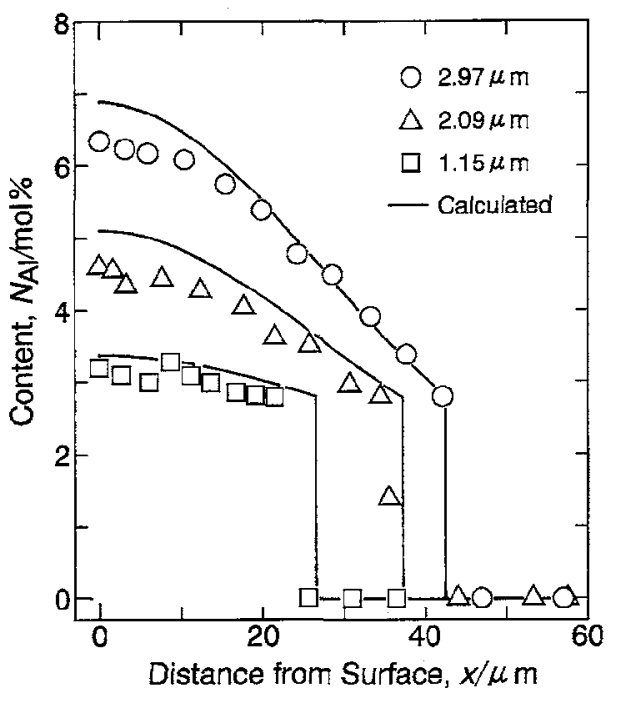

Fig. 4 Al content profiles near the Al-diffused layer.

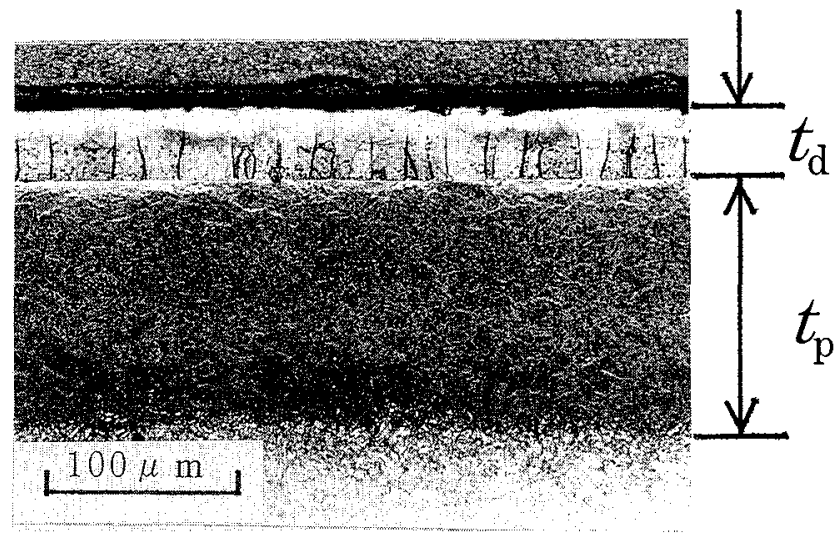

Fig. 5 Optical micrograph showing the Al-diffused nitriding layer $\left(t_{\mathrm{d}}\right)$ and the nitriding layer of the parent material $\left(t_{\mathrm{p}}\right)$. Thickness of the $\mathrm{Al}$ thin film: $2.5 \mu \mathrm{m}$, nitriding: at $853 \mathrm{~K}$ for $14.4 \mathrm{ks}$.

特定できなかった。

$\mathrm{Al}$ 膜形成一桩散一焼入机一窒化処理した試料の断面顕微鏡組 織をFig. 5 K示す。図に打いて認められる最表面の白色層 は窒化された $\mathrm{Al}$ 拡散層である。一方, 窒化された $\mathrm{Al}$ 拡散 層直下の黑く腐食された部分は母材 SKD61の窒化層であ る.ここでは, $\mathrm{Al}$ 拡散窒化層と母材窒化層とを合わせて全 窒化層と呼ぶことにする.Fig. 6 にSKD61 の全窒化層厚さ 抢よび母材窒化層厚さの Al 膜厚さへの依存性を示す．図に 版いて認められるょらに， $813 \mathrm{~K}$ 和よび $853 \mathrm{~K}$ のいずれの 温度においてる全窒化層厚さは $\mathrm{Al}$ 膜厚さに依存することな くほとんど一定でする。一力, 窒化温度のような低い温度で の $\mathrm{Al}$ 拡散層の成長は無視しても差し支えないであるら。こ のことを考慮に入れると, 拡散層厚さと拡散窒化層厚さとは 同一の厚さとみなすことができる。既にFig. 4 に示したよ らに, $\mathrm{Al}$ 拡散層厚さは $\mathrm{Al}$ 膜厚さとともに增大する。したが 


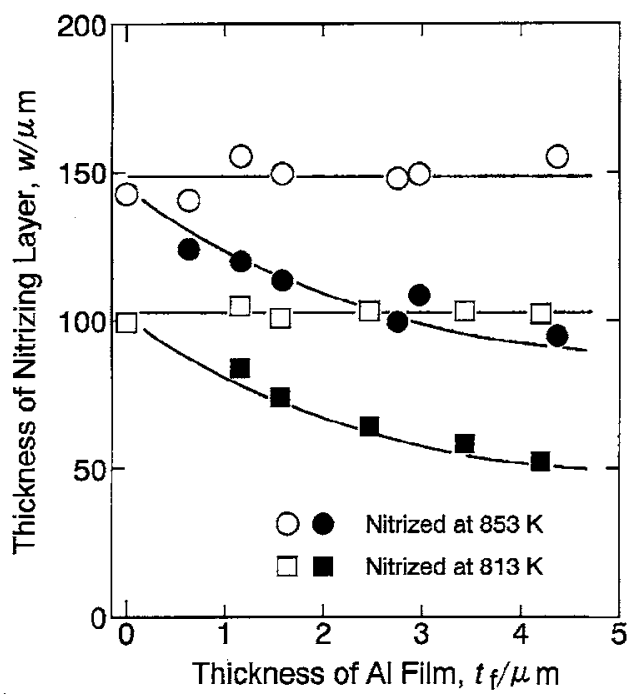

Fig. 6 Dependences of the thickness of total nitriding layer $(O, \square)$ and that of nitriding layer in the parent material $(\bullet$, m) upon the thickness of the Al thin film.

って，Fig. 6 は，その分，母材窒化層厚さが $\mathrm{Al}$ 膜厚さとと もと減少することを示するのと考光られる。

$\mathrm{A} 1$ 膜形成-昖散-焼入れ-窒化処理したSKD61 の表面付近 の窒素, 炭素扰よびアルミニウムの分布状況を調べるため に，EPMA を用いて各特性 X 線強度の線分析を行った。そ の結果をFig. 7 亿示寸。図に和いて，Al 拡散窒化層と母材 窒化層との間では $\mathrm{Al}$ 濃度および $\mathrm{N}$ 濃度が不連続に变化して いることが認められる。一方，単に窒化のみを行った SKD61の表面付近のC 濃度就よび $\mathrm{N}$ 濃度の推移曲線を Fig. 8 亿示す. Fig. 7 拉よび Fig. 8 からは，母材窒化層か ら母材へと移行するにつれて $\mathrm{N}$ 濃度の急激な減少と C 濃度 の急激な增加が，末たC 濃度はその後の内部への移行とと もに緩慢に減少することが認められる。な拉，GDS(グロー 放電分光分析) 飞よる測定に执いても，緩慢な变化ながら，

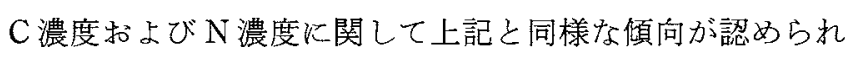
た.

Fig. 7 拈よび Fig. 8 亿認められる N 濃度の減少に伴う C 濃度の立ち上がりは，多成分拡散に扔いて認められているア ップヒル拡散(6)(7)である。このことについて以下に考察す る、いま簡単のために, SKD61 ダイス鋼に含まれるC, N 以外の元素の影響を無視することにする。ささらに，Nのモ 儿分率怯互いに隣接する母材窒化層と母材との間では $x_{\mathbb{N}}$ か ら0 亿不連続俚变化すること,ならびにC の活量 $a_{\mathrm{C}}$ と Cの モル分率 $x_{\mathrm{C}}$ との間には Henry の法則( ${ }^{(8)}$ が成り立つことを仮。

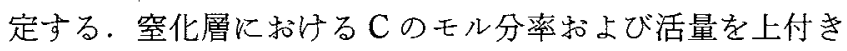
添光字 $\mathrm{s}$ 亿って，窒化層飞隣接する村位置でのCのモ 儿分率扰よび活量を上付き添光字 $\mathrm{m}$ 飞よって区別すると， それぞれのCの活量は次式によって与兄られる。

$$
\begin{aligned}
& a_{\mathrm{C}}^{\mathrm{s}}=\gamma_{\mathrm{C}} \cdot x_{\mathrm{C}}^{\mathrm{s}}+\varepsilon_{\mathrm{C}}^{(\mathrm{N})} \cdot x_{\mathrm{N}} \\
& a_{\mathrm{C}}^{\mathrm{m}}=\gamma_{\mathrm{C}} \cdot x_{\mathrm{C}}^{\mathrm{m}}
\end{aligned}
$$

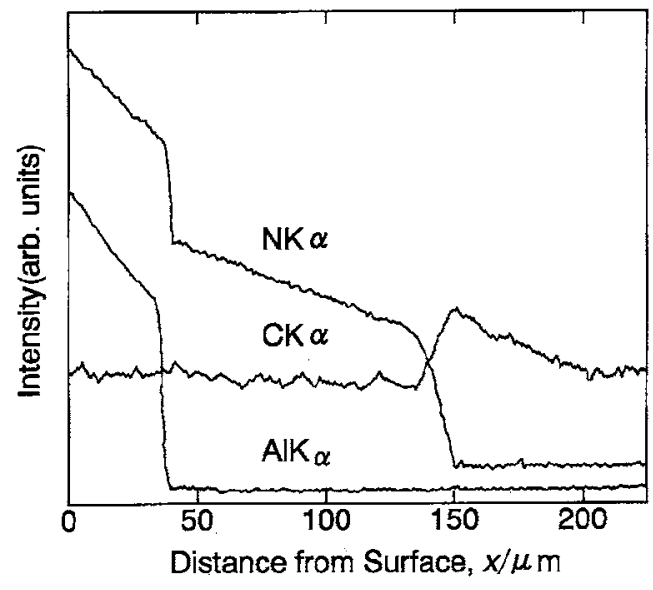

Fig. 7 Intensity profiles of characteristic X-ray lines for the specimen which was Al-diffused, quenched, and nitrided at 853 $\mathrm{K}$ for $14.4 \mathrm{ks}$. Thickness of the Al thin film: $3.0 \mu \mathrm{m}$.

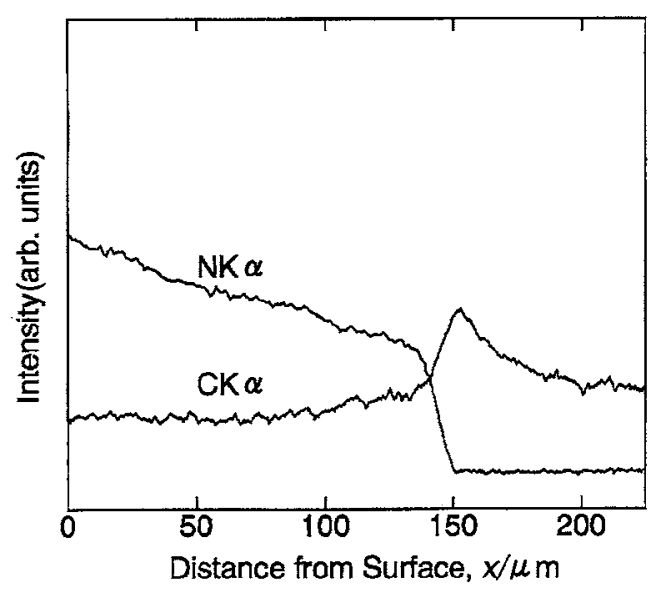

Fig. 8 Intensity profiles of characteristic $\mathrm{X}$-ray lines for the specimen which was nitrided at $853 \mathrm{~K}$ for $14.4 \mathrm{ks}$.

ここに, $\gamma_{\mathrm{C}}$ はCの活量係数, $\varepsilon_{\mathrm{C}}^{(\mathrm{N})}$ はオーステナイト中の $\mathrm{C}$ に対する Nの相互作用母保数である. 文献次よると年，拡 散加熱温度 $1298 \mathrm{~K}$ に括ける $\varepsilon_{\mathrm{C}}^{(\mathrm{N})}$ の值は6.78である。隣接す る窒化層と母材との間では, 互いにCの活量が等しい。し たがって，式(2)款よび(3)から次式が成立する。すなわ b

$$
x_{\mathrm{C}}^{\mathrm{m}}=x_{\mathrm{C}}^{\mathrm{s}}+6.78 x_{\mathrm{N}} / \gamma_{\mathrm{C}}
$$

上式より， $x_{\mathrm{C}}^{\mathrm{m}}>x_{\mathrm{C}}^{\mathrm{s}}$ であることが明らかである. 式 $(4)$ は窒 化層が成長していく窒化処理全般にわたって妥当なので, 結 果的にはFig. 7 亦たはFig. 8 に認められるよ5に, 窒化層 中の炭素が排除されて，母材側伦押し边められていく現象を 呈することになる.

種々の厚さの $\mathrm{Al}$ 膜厚さを持つ試料に関して, 拡散一焼入 れ-窒化処理した試料の表面硬さを Fig. 9 亿示す. 図から表 面硬さは $\mathrm{Al}$ 膜厚さとともに嚾かながら増加していくことが わかる。な拉, $813 \mathrm{~K}$ 特よび $853 \mathrm{~K}$ の窒化温度の差による 


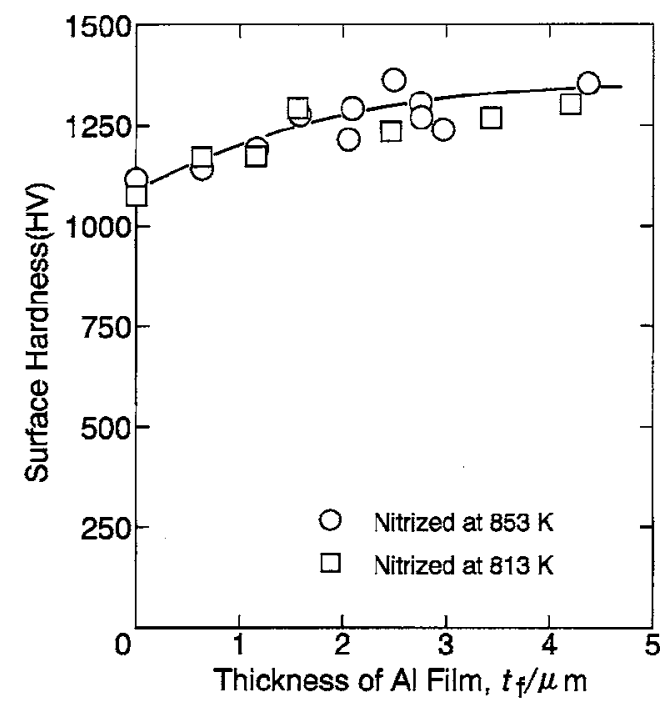

Fig. 9 Dependence of the surface hardness upon the thickness of the Al thin film. Nitriding time: $14.4 \mathrm{ks}$.

表面硬さの違いは汪とんど認められない，Al 薄膜形成拉よ び拡散加熱挠，齐入れした試料の断面硬さ推移曲線，ならび にその後, プラズマ窒化した試料の断面硬さ推移曲線をとも に Fig. 10 亿示す。焼入れ後の試験片に打いては，内部母材 は本試料の炭素量炕相当する約 HV610 のマルテンサイト硬 さを示すのに対し，拡散層はHV270 程度の低い硬さを示す にすぎない，Al 拡散層がこのよらに低い硬さを示すのは, もちろん，この層が急冷操作炕って焼入れ硬化することの ないフェライト組織であるからである。窒化後の硬さ推移曲 線は $\mathrm{Al}$ 拡散窒化層, 母材窒化層, 打上び焼入㣗後, 窒化温 度での加熱炕よって焼きもどしを受けた母材の硬さ值から成 り, 全体として表面に近つくに従って階段状浭さ値が増加 する傾向を示す．窒化硬さが鋼中の $\mathrm{Al}$ 含有率とともに著し く高くなることは既㑢告されて和り ${ }^{(10)}, \mathrm{Al}$ 拡散窒化層の 硬さ值が高いのはこのことを裏付けるるのである。な据， Fig. 7 K执いて, Al 昖散窒化層に抽いては $\mathrm{Al}$ 濃度と $\mathrm{N}$ 濃 度との距離依存性が，母材窒化層飞拈いては N濃度の距離 依存性が明白浔認められる。李た，Fig. 4 および Fig. 9 か ら表面硬さは表面 $\mathrm{Al}$ 濃度ととも焙くなることが明らかで ある。こ礼らのことから，少なくとも $\mathrm{Al}$ 拡散窒化層内の断 面硬さは表面に近づくに従って高くなるものと推定される。 しかし，Fig. 10 に沶いては硬さの距離依存性は認められな かった。これは，測定荷重が $4.9 \times 10^{-2} \mathrm{~N}$ と小さいため， 読み取り硬さ値の誤差が大きかったことによるものと考兄ら れる.

$\mathrm{A} 1$ 膜形成-拡散一焼入れ-窒化処理した試料，および SKD61 素材を単に加熱-焼入れ-䇪化処理した試料の X 線回折パター ンをともに Fig. 11 亿示す. 図と沶いて，4種類のいずれの 試料に怙いても， $\varepsilon-\mathrm{Fe}_{2-3} \mathrm{~N}$ 打よび $\gamma^{\prime}-\mathrm{Fe}_{4} \mathrm{~N}$ が認められる。 一方， $\alpha \mathrm{Fe}$ なは $\alpha^{\prime}-\mathrm{Fe}$ は，上記ピークと重畳している可

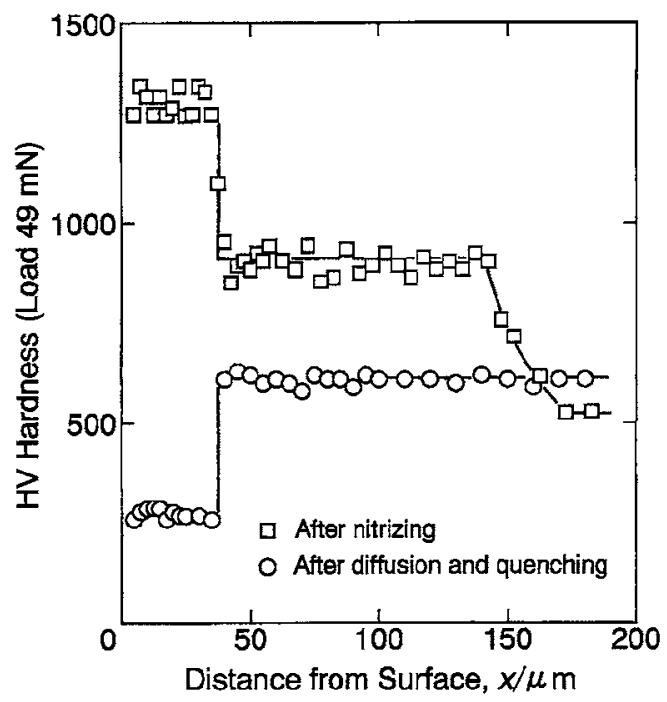

Fig. 10 Hardness profiles on the cross section of the specimen which was Al-diffused, quenched, and that of the specimen Al-diffused, quenched, and nitrided. Thickness of the Al thin film: $2.5 \mu \mathrm{m}$, nitriding: at $853 \mathrm{~K}$ for $14.4 \mathrm{ks}$.

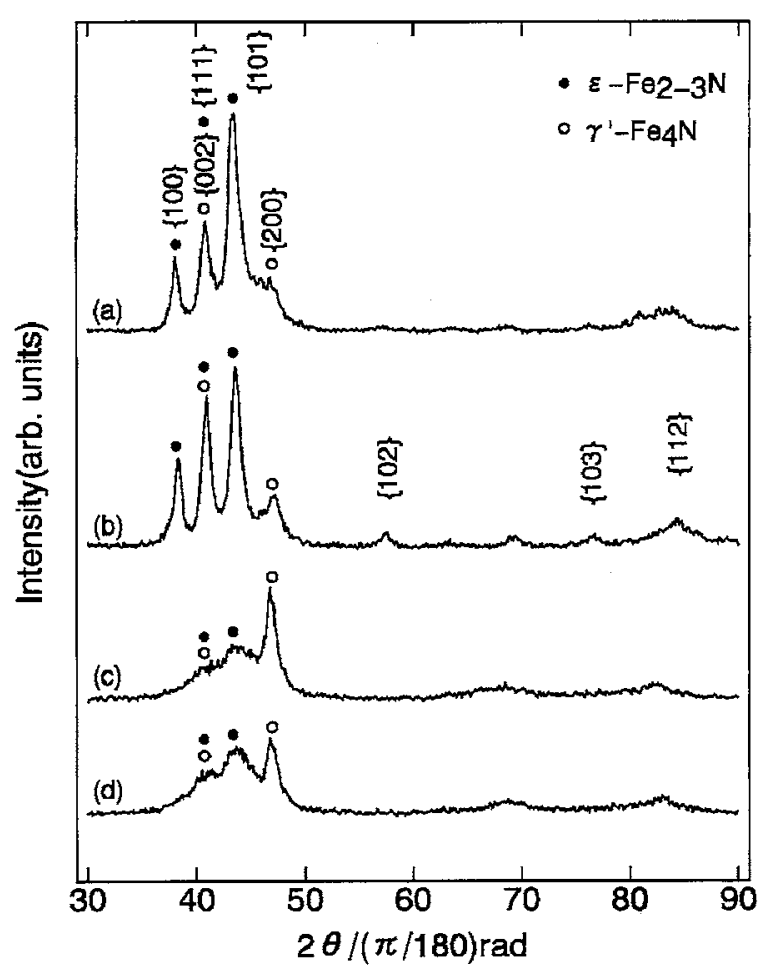

Fig. 11 X-ray diffraction patterns of (a) the specimen nitrided at $813 \mathrm{~K}$, (b) the specimen nitrided at $853 \mathrm{~K}$, (c) the specimen Al-diffused, quenched, and nitrided at $813 \mathrm{~K}$, and (d) Al-diffused, quenched, and nitrided at $853 \mathrm{~K}$. Thickness of the $\mathrm{Al}$ thin film: $2.5 \mu \mathrm{m}$, nitriding time: $14.4 \mathrm{ks}$.

能性はあるものの，明確に同定することはできなかった。 SKD61素材空化層に持いては43.7 近辺に認められる $\varepsilon^{-}$ $\mathrm{Fe}_{2-3} \mathrm{~N}\{101\}$ ピークが46.9 近辺に認められる $\gamma^{\prime}-\mathrm{Fe}_{4} \mathrm{~N}\{200\}$ 
のピークより高い強度を示し，逆に $\mathrm{Al}$ 拡散窒化層において

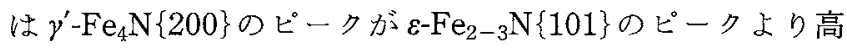
い強度を示寸。したがって，SKD61素材窒化層に和ける窒 化物は相対的に多く $\varepsilon-\mathrm{Fe}_{2-3} \mathrm{~N}$ から構成されるのに対し， $\mathrm{Al}$ 拡散窒化層に持讨る窒化物は相対的に多く $\gamma^{\prime}-\mathrm{Fe}_{4} \mathrm{~N}$ 加成り 立つ。

回折線ピークのブロードニングは 3 つのタプの格子欠 宿すなわち結晶格子のひずみ，結晶の積層不整そして結晶粒 の微小サイズによって生じるものといわれている(11)。著者 の一人は市販電熱材料 [公称成分 (mass\%) $\mathrm{Cr}: 22, \mathrm{Al}: 5.3$,

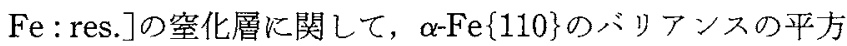
根とともに表面硬さが直線的に高くなる傾向を認めた(12). な拝，バリアンスの平方根は回折ピークの幅を表す量であ る(11)。一方，本研究に和いては，いずれの試料の，いずれ の窒化物のピークもブロードな傾向を示すが，特にこの傾向 は $\mathrm{Al}$ 拡散窒化層の $43.5^{\circ}$ 近辺のプロファイルに招いて著し い.このことは，Fig. 7 和よびFig. 8 の比較から明らかな ように， $\mathrm{Al}$ 拡散窒化層が素材窒化層より高い窒素含有率を 持つことにも依存していると考兄られる、結果として，この ことがAl 挫散窒化層が素材窒化層より高い硬さを示すこと に笴与していると考它られる。

\section{N. 結 論}

スパッタリングによる Al 薄膜形成, 温度 $1298 \mathrm{~K}$ 牞よび 時間 $1.8 \mathrm{ks}$ での真空加熱による $\mathrm{Al}$ 薄膜と母材との合金化， 焼入れ，その後の窒化上り成る複合化処理により，合金工具 鋼 SKD61の表面硬化を試みた。得られた結果を次に要約す る.

（1） $\mathrm{Al}$ 拡散層の厚さは， $\mathrm{Al}$ 薄膜の厚さとともに増加し， 薄膜厚さの約11倍以上の厚さの拡散層が形成される。拡散 層表面の $\mathrm{Al}$ 含有率も薄膜厚さととも火増加する。

(2) $\mathrm{Al}$ 薄膜厚さおよび $\alpha /(\alpha+\gamma)$ 境界組成から，数值計算 によって $\mathrm{Al}$ 濃度推移曲線を予測することができる。

（3）窒化領域は $\mathrm{Al}$ 拡散窒化層牞よび母材窒化層から成 り，その全窒化層の厚さは $\mathrm{Al}$ 薄膜厚さとは無関係にほぼ一 定である.

（4）窒化層の表面硬さは，Al 薄膜厚さとともに僅かに増 加し，窒化温度 $813 \mathrm{~K}$ と $853 \mathrm{~K}$ との間ではあ⿱り差は認め られない。
（5） A1 薄膜形成-真空加熱-嗦入れ処理した試料に関して は，拡散層は軟質で，丹材が焼入れ硬化した内部上がりの階 段状硬さ推移曲線を示す。

(6) $\mathrm{Al}$ 薄膜形成-真空加熱-焼入れ-窒化処理した試料に関 しては，拡散窒化層，母材窒化層和よび母材の順に硬さ值が 低くなっていく内部下がりの階段状硬さ推移曲線を示す。

（7）窒化試料に関しては，窒素の内部への浸透とともに炭 素が母材内部へ押し込められていくアップヒル拡散が認めら れる。

(8) 拡散窒化層の回折線ピークのブロードニングは母材窒 化層のそれに比較して著しい。

本窒化試料の C 濃度扎よび $\mathrm{N}$ 濃度推移曲線に関する熱力 学的検討に当たり，適切な助言と相互作用助係数に関する 文献を紹介いただいた大阪府立大学工学部機能物質科学科 杉野重明氏に深謝いたします。京，本研究を進めるに当た っては帝京大学理工学部横堀武夫学部長より多大の協力をい ただいたことに愿く感謝いたします。さらに，大阪府立産業 技術総合研究所評価技術部 浦谷文博氏には GDS 分析に関 して協力いただき，本学科技術職員 伊藤正則氏には試料作 成，熱処理およびプラズマ窒化と本研究に関して幅広い支援 をいただいた。ここに記して謝意を表します。

\section{文献}

（1）过 新次：日本金属学会誌, $\mathbf{5 9}$ (1995), 726 .

(2) E. P. Bertin: Introduction to X-ray Spectrometric Analysis, Plenum, New York, (1980), p. 382.

（3）JIS ヘンドブック鉄鋼-1989:日本規格協会，(1989）, p. 1475.

（4）大和久重雄：表面技術，41(1990), 594.

(5) 过 新次, 頃安貞利: 日本金属学会誌, 61(1997), 8 .

(6) L. Darken: Trans. AIME, 180(1949), 430.

(7) J. S. Kirkaldy and D. J. Young: Diffusion in the Condensed State, The Institute of Metals, Ohio, (1987), p. 15.

(8) R. A. Swalin: Thermodynamics of Solids, John Wiley \& Sons, New York, (1962), p. 100

（9）盛 利貞, 井上道夫，郡司好喜，成田貴一：第 1 回西山記念 技術講坐 鉄鋼製鍾の基礎，日本鉄鋼協会，(1968）, p. 14 .

(10) C. A. Stickels: Metal Handbook, vol. 4, American Society for Metals, Metal Park, (1981), p. 191.

（11）講座・現在の金属学実験技術集 2 , 金属の物理的湘定法 I, 日本金属学会, (1981), p. 171 .

(12) 辻 新次：大阪大学接合科学研究所共同研究報告，1995年度, p. 106. 